\title{
Specific Characteristics of Business Negotiation in the SEE Trading Companies
}

\author{
Article history: \\ Received: 15 December 2013 \\ Sent for revision: 11 February 2014 \\ Received in revised form: 25 March 2014 \\ Accepted: 31 March 2014 \\ Available online: 19 May 2014
}

\begin{abstract}
The aim of this paper is to determine, based on empirical research, whether there is a statistically significant correlation between the cultural, economic and political factors, and business negotiation in the trade sector of selected countries in the South-Eastern Europe (SEE): Serbia, Croatia, Bosnia and Herzegovina, Hungary and Montenegro. Data on the research problem are collected electronically through questionnaires, while obtained results are interpreted by using parametric statistical tests: a two-way Analysis of Variance (ANOVA) test and the Least Significant Difference (LSD) test. After obtained results are analyzed, the empirical research has shown that there is a significant correlation between the aforementioned factors and business negotiation, which served as a basis for creating the profile of a business negotiator in regional trade companies. The research results provide the grounds for future researches that should examine the impact of subgroups within the analyzed factors on the success of business negotiation.
\end{abstract}

Keywords: business negotiation, trade, trade companies, human resources, etc.

\section{Specifična obeležja poslovnog pregovaranja u trgovinskim kompanijama južno-istočne Evrope}

Apstrakt: Cilj ovog rada je da se na bazi empirijskog istraživanju utvrdi da li postoji statistički značajna povezanost između kulturnih, ekonomskih i političkih faktora i poslovnog pregovaranja u trgovinskom sektoru izabranih zemalja južno-istočne Evrope: Srbije, Hrvatske, Bosne i Hercegovine,

\footnotetext{
${ }^{1}$ Edukons University, Faculty of Business Economics, radenko.maric@yahoo.com

${ }^{2}$ Comenius University, Faculty of Management in Bratislava, Slovakia 
Marić R., Janać J.: Specific Characteristics of Business Negotiation in the SEE...

Mađarske i Crne Gore. Prikupljanje podataka o istraživačkom problemu rađeno je elektronskim putem na bazi upitnika, dok su za tumačenje dobijenih rezultata korišćeni parametarski statistički testovi: test analize varijanse sa dva fatora varijabiliteta (ANOVA test) i test najmanje značajne razlike (NZR test). Na osnovu sagledavanja dobijenih rezultata, empirijsko istraživanje je pokazalo da postoji značajna povezanost između pomenutih faktora $i$ poslovnog pregovaranja, na bazi čega je kreiran profil poslovnog pregovarača u regionalnim trgovinskim kompanijama. Rezultati istraživanja predstavljaju osnovu za buduća istraživanja koja bi trebalo da sagledaju uticaj podgrupa unutar analiziranih faktora na uspeh poslovnog pregovaranja.

Ključne reči: poslovno pregovaranje, trgovina, trgovinske kompanije, ljudski resursi.

\section{Introduction}

Trade plays a key role in development of integrated market economy and takes an important place in overall economy of the SEE countries. This is supported by data reporting that in the period from 2006 to 2012, the share of trade in GDP ranged from $11 \%$ to $14 \%$, and from $35 \%$ to $41 \%$ in total income of the analyzed countries, while GDP of trade expressed growing tendency from $14 \%$ to $16 \%$, which is significantly above the achieved real growth of total GDP in the selected SEE countries, from 5\% to 7\% (Miljković, 2012; Ćuzović, 2011). These data confirm the fact that trade will play a crucial role in future economic development and accession of SEE countries into the EU. Therefore, special attention must be paid to this segment of service industry, with a special emphasis on importance of human resources and negotiation process in achieving business success of trading companies.

In modern corporate business, differentiation between successful and unsuccessful companies is, inter alia, based on capability of the management to carry out successful business negotiations. The research conducted by American Management Association shows that the main reason for run-down of $80 \%$ of companies in the USA lies in poor management and inefficient business negotiating (American Management Association, 2005). On the other hand, the research carried out on the presence of economic crisis in Serbian companies on sampled 68 organizations has also shown that internal factors caused emergence of crisis in two-thirds of analyzed companies, and that the most important cause of crisis lies in mistakes made by the management, mistakes in human resources management, negotiation and communication, etc. (Vojnović, Vojnović, Grujić, 2011).

Various authors interpret negotiation in different ways. Some of them regard it as primary task of managers that is critical to company's business success 
Marić R., Janać J.: Specific Characteristics of Business Negotiation in the SEE...

(Mintzberg, 1983; Neale, Bazerman, 1992; Kaufman, Carter, 2004; Križman, Kalanj, 2008). Others see it as a fundamental skill that is crucial not only for successful operations but also for successful living (Lewicki, Saunders, Barry, 2009; Dobrijević, 2009). Basically, it is a means of deciding, where two or more parties tend to communicate in order to fulfil their needs, desires and interests (Cohen, 1982), reconcile differences, resolve conflicts and disputes (Dobrijević, 2009), and finally ensure business cooperation (Marić, VemićĐurković, Hevizi, 2012).

Business negotiating in trade companies is usually associated with two fields of performing business operations: the first is commercial field, i.e. buying or selling, and the second field is relations within companies, i.e. relations between the management and employees, employees and clients, owners and managers, etc. It is also useful to have negotiation skills in many other fields, such as: negotiating delivery time and method, storage of goods, trade margins, lease of infrastructure and land, then employees' vacation periods, amount of personal income and advancement conditions, schedule of meetings, etc. Given the specific features of trade as primarily an international business activity, authors emphasize the importance of international factors for the process of negotiation and behaviour of employees, such as: laws and policies of other countries, diversity of currencies, government bureaucracy (Salacuse, 1991); cultural characteristics of negotiators; heritage, psychological characteristics (Acin-Sigulinski, 2003); ideological, economic and political factors, etc. (Dupuis, Prime, 1996).

Consequently, negotiating in trading sector can be seen as an international process of communicating and reaching agreements with business partners, which requires negotiators to have good knowledge of negotiation language, culture, religion, tradition and custom of all parties involved in negotiations, national values and issues, as well as economic and political landscape (Whalley, 1998). The key research questions are: What is the real impact of given factors on the attitudes of negotiating parties in trade companies? Which is the most important factor for achieving success in negotiations? Is it possible to design a standardized profile of a manager- negotiator?

\section{Methodology of research}

In order to create a profile of a potential business negotiator in trade companies, the basic aim of the research is to examine whether and to what extent factors such as country, culture, language, customs, religion, national issues, economic and political landscape affect achievement of success in negotiation process. In this context, the following hypotheses have been set up: 
Marić R., Janać J.: Specific Characteristics of Business Negotiation in the SEE...

- Null hypothesis Ho1 is: differences in the number of successfully completed negotiations in trade companies depending on the cultural, economic and political factors are significant, i.e. the offered alternative hypothesis $\mathrm{Ha} 1$ is that these differences are random.

- Null hypothesis $\mathrm{Ho2}$ is: differences in the number of successfully completed negotiations in trade companies depending on the country where a trading company operates are statistically significant, i.e. the offered alternative hypothesis $\mathrm{Ha} 2$ is that these differences are random.

If hypotheses $\mathrm{Ho} 1$ and $\mathrm{Ho} 2$ are confirmed, i.e. if we find that there are statistically significant differences between the observed statistical characteristics, we will test to see which characteristic has the single highest impact on managers' attitudes and success in business negotiations.

The analysis of hypotheses and interpretation of the results were performed through parametric statistical tests, such as: a two-way Analysis of Variance (ANOVA) test, and the Least Significant Difference (LSD) test. For testing hypotheses by using ANOVA test, we compare the calculated $F$ value with the table value $F$ (Fcrit.), which is read from the F-table for a given level of reliability $\alpha=0,05$ and number of degrees of freedom $(m-1)^{\star}(s-1)$. $F$ value is calculated on the basis of the following formulas:

$F=\frac{V a / b}{V r}$

Where:

- $\mathrm{Va} / \mathrm{b}$ - is the evaluation of factorial variance that is calculated for examined groups of factors (a) and (b) by using the following formulas:

$V a=\frac{S a}{m-1}=\frac{\sum_{i=1}^{m} s\left(\overline{x_{i}}-\bar{x}\right)^{2}}{m-1}$,

$V b=\frac{S b}{s-1}=\frac{\sum_{i=1}^{m} m\left(\overline{x_{j}}-\overline{\bar{x}}\right)^{2}}{s-1}$,

Where:

- $m$ - number of factor (a),

- $s$ - number of factor (b),

- $\overline{x_{i}}$ - the arithmetic mean of the sample by rows.

- $\overline{x_{j}}$ - the arithmetic mean of the sample by columns. 
Marić R., Janać J.: Specific Characteristics of Business Negotiation in the SEE...

- $\quad \bar{x}$ - total average of all observations.

- $\mathrm{Vr}$ - is an evaluation of residual variance, calculated according to formula:

$V_{r}=\frac{S r}{(m-1)(s-1)}=\frac{\sum_{i=1}^{m} \sum_{j=1}^{s}\left(x_{i j}-\bar{x}\right)^{2}-S a-S b}{(m-1)(s-1)}$

If $F>$ Fcrit, formulated null hypothesis Ho is accepted, while the offered alternative hypothesis $\mathrm{Ha}$ is rejected, and vice versa.

Testing the impact of each individual data on business negotiation is done by using the Least Significant Difference - LSD test. LSD test is used when testing whether there is a statistically significant difference between the arithmetic means of the given characteristics, formulating that such difference is statistically significant if the condition $\left(\bar{X}_{t}-\bar{X}_{t}+1\right)>\operatorname{LSD}$ is met, and is marked with $\left(^{*}\right)$ for a given characteristic. Least Significant Difference LSD is calculated based on the following formula:

$$
L S D=t_{(\alpha, n-m)} * S_{\left(\bar{x}_{i}-\bar{x}_{i+1}\right)}, i=1,2, \ldots . m,
$$

Where:

- $\quad t_{(\alpha, n-m)}$ - a table value read from t-table for the risk of error $\alpha=0,05$ and number of degrees of freedom n-m.

- $S_{\left(\bar{x}_{i}-\bar{x}_{i+1}\right)}$ - a standard error of the difference between two means that is calculated by formula

$$
S_{\left(\bar{x}_{i}-\bar{x}_{i+1}\right)}=\sqrt{\frac{V r}{n_{i}}}, \text { for } n_{1}=n_{2}=\ldots=n_{i}=n_{m}
$$

The research was conducted in April-June 2012, as part of a major research project of IPA - "Cross-border learning region: examination of universities' possible role in the economic development of the Hungarian-Serbian crossborder region - HUSRB/1002/216", and in June-August 2013, on the basis of e-survey studies. The study included 212 employed managers (middle, higher and top level) in the selected SEE trading companies. $31 \%$ of the companies operate in the market of the Republic of Serbia, mainly large retail chains of DIS, Delhaize Group, Mercator, Metro Cash and Carry, etc.; 23\% of the companies operate in Hungary, such as Tecso, Adeco, etc., $19 \%$ of the companies are in Croatia, such as Lidl, Konzum, Špar, etc., 12\% of the 
Marić R., Janać J.: Specific Characteristics of Business Negotiation in the SEE...

companies are from Bosnia and Herzegovina, like DP Market, Bingo Tuzla, etc., and $15 \%$ of the companies operate in the market of Montenegro, such as Roda, Ekspo, etd. Surveying technique was used for collecting data on the research problem. A multiple choice survey was used as an instrument of research. The research was conducted electronically on the basis of an anonymous questionnaire comprising 11 questions.

\section{Results}

The researched sample consisted of SEE trading companies. Total of 212 managers were examined via survey. Out of that number, $21 \%$ of analyzed managers belong to top management, the most responsible people for development and success of a trade company, for making crucial strategic decisions regarding its competitive capabilities and market position, operating methods and other vital issues. Out of the total survey sample, $33 \%$ of managers belong to the middle management level, responsible for operations of departments, units, divisions, and they work closely with top management, also significantly affect the overall organizational strategy and success of a company. The largest part of the analyzed managers, $46 \%$ belong to the lowest level of management often considered as the key level in the company since it converts long-term goals and strategies into actual results Representativeness of the sample can be confirmed by the following data: number of employees in the surveyed companies make $56 \%$ of the total number of employees in trade, they account for over $60 \%$ in total turnover of goods and services, given the realized income, and the listed companies are among top ten largest companies in their respective countries, while they are among top three companies in trade sector, etc. (Deloitte, 2013). The above sample in the research is illustrated by Table 1.

Table 1. Levels of analyzed managers and research sample

\begin{tabular}{ccc}
\hline Management levels & Number of respondents & Frequency \\
\hline Lower & 98 & $46 \%$ \\
Middle & 70 & $33 \%$ \\
Top & 44 & $21 \%$ \\
\hline Total & 212 & $100 \%$ \\
\hline
\end{tabular}

Source: Author

The following Table 2 shows the results obtained from answers provided by managers grouped in five countries in which analyzed trade companies operate. Within this research, the managers were asked to respond which of the above factors (column 1) was critical to achieving success in business 
Marić R., Janać J.: Specific Characteristics of Business Negotiation in the SEE...

negotiations in which they participated. For example, if we look column 2 (Serbia) in the table, number 10 for factor of National issues means that 10 managers from trading companies operating in the Serbian market responded that the key factor for reaching an agreement in negotiations with foreign partners is appreciation of Serbian national issues. On the other hand, we have an example, where in column 3 (Croatia), number 8 for factor of Political landscape means that 8 managers from trading companies operating in Croatia responded that political landscape in their country is factor that determines success in negotiations. The following table illustrates detailed answers selected by countries and factors:

Table 2. Impact of key factors on business negotiation

\begin{tabular}{|c|c|c|c|c|c|c|}
\hline Factor/ Country & Serbia & Croatia & $B$ and $H$ & Hungary & Montenegro & Total \\
\hline 1 & 2 & 3 & 4 & 5 & 6 & 7 \\
\hline Culture & 9 & 11 & 9 & 11 & 8 & 48 \\
\hline $\begin{array}{l}\text { Language } \\
\text { barrier }\end{array}$ & 7 & 7 & 10 & 4 & 6 & 34 \\
\hline $\begin{array}{l}\text { Tradition, } \\
\text { custom and } \\
\text { religion }\end{array}$ & 9 & 10 & 8 & 9 & 8 & 44 \\
\hline National issues & 10 & 7 & 8 & 5 & 5 & 35 \\
\hline $\begin{array}{l}\text { Economic } \\
\text { situation }\end{array}$ & 6 & 4 & 6 & 4 & 4 & 24 \\
\hline $\begin{array}{l}\text { Political } \\
\text { landscape }\end{array}$ & 7 & 8 & 5 & 3 & 4 & 27 \\
\hline Total & 48 & 47 & 46 & 36 & 35 & 212 \\
\hline
\end{tabular}

Source: Author

\section{Discussion}

To test formulated hypotheses and discuss the results of the research, parametric statistical test of two-way analysis of variance - ANOVA test shall be used. Necessary information for data testing and discussion is illustrated by the following tables - Table 3 and Table 4.

Table 3. Review of basic statistical values of business negotiations in trade companies by factors and countries

\begin{tabular}{ccccc}
\hline Review & Number & Sum & $\begin{array}{c}\text { Arithmetic } \\
\text { mean }\end{array}$ & Variance \\
\hline 1 & 2 & 3 & 4 & 5 \\
\hline
\end{tabular}


Marić R., Janać J.: Specific Characteristics of Business Negotiation in the SEE...

\begin{tabular}{lcccc}
\hline Culture & 5 & 48 & 9,6 & 1,8 \\
Language barrier & 5 & 34 & 6,8 & 4,7 \\
$\begin{array}{l}\text { Tradition, custom and } \\
\text { religion }\end{array}$ & 5 & 44 & 8,8 & 0,7 \\
National issues & 5 & 35 & 7 & 4,5 \\
Economic situation & 5 & 24 & 4,8 & 1,2 \\
Political landscape & 5 & 27 & 5,4 & 4,3 \\
& & & & \\
Serbia & 6 & 48 & 8 & 2,4 \\
Croatia & 6 & 47 & 7,83 & 6,16 \\
Bosnia and Herzegovina & 6 & 46 & 7,66 & 3,46 \\
Hungary & 6 & 36 & 6 & 10,4 \\
Montenegro & 6 & 35 & 5,83 & 3,36 \\
\hline
\end{tabular}

Source: Author

Table 3 illustrates the basic statistical parameters of the observed data, such as: arithmetic mean and variance. Arithmetic mean (column no.4) shows the average value for a given characteristic, for example: arithmetic mean of 9.6 for Culture shows that on average 9.6 managers in each analyzed country believe that this characteristic is a key factor for achieving success in business negotiations. On the other hand, variance (column no.5) shows squared deviations of each data in a given row or column from the arithmetic means of that row or column.

Table 4. Two-way analysis of variance ANOVA test

\begin{tabular}{lcccccc}
\hline $\begin{array}{l}\text { Source of } \\
\text { variation }\end{array}$ & SS & $d f$ & $M S$ & $F$ & P-value & F crit \\
\hline Factors (a) & 87,06666667 & 5 & 17,41333333 & 8,305246 & 0,000221 & 2,710890 \\
Countries (b) & 26,86666667 & 4 & 6,7166666667 & 3,203498 & 0,034702 & 2,866081 \\
Standard error & 41,93333333 & 20 & 2,096666667 & & & \\
\hline Total & 155,8666667 & 29 & & & & \\
\hline
\end{tabular}

Source: Author

Table 4 presents the necessary calculated data for testing formulated hypotheses by using statistical parametric test - ANOVA.

The first set up hypothesis Ho1 is that differences in the number of successfully completed business negotiations in the selected SEE trade companies, depending on the cultural, economic and political factors, are 
Marić R., Janać J.: Specific Characteristics of Business Negotiation in the SEE...

statistically significant, i.e. alternative to formulated hypothesis Ha1 is that those differences are random. Table 4 reads from the row Factors the value $\mathrm{F}$ $=8,305246$ (1), i.e. Fcrit $=2.71089$, then $95 \%$ for level of reliability or $\alpha=0.05$ for risk of error. Based on the ANOVA test, given that $F=8.305246>$ Fcrit $=$ 2.71089 , we conclude that, at the risk of error of $5 \%$, null hypothesis Ho1 is accepted, and alternative hypothesis Ha1 is rejected, which means that differences in the number of successfully completed business negotiations, depending on the cultural, economic and political factors are statistically significant. This means that success of negotiations in trade companies in the selected SEE countries is significantly affected by factors such as culture, religion, language, custom, national issues, politics, economics, etc. Conclusion is additionally supported by testing, using the $\mathrm{P}$ value. According to the given test, if the calculated $P$ value is less than risk of error $\alpha$, there is strong $(P<0.01)$, moderate $(0.01<P<0.05)$ or just indicated $(0.05<P<0.10)$ evidence against the alternative hypothesis $\mathrm{Ha}$. We can draw a conclusion in our research that there is strong evidence against the alternative hypothesis Ha1, since we have calculated $\mathrm{P}=0.000221<0.01$ for given row Factors.

The second formulated hypothesis $\mathrm{Ho} 2$ is that differences in the number of successfully completed business negotiations, depending on country in which a trade company operates are statistically significant, i.e. alternative to hypothesis $\mathrm{Ha} 2$ is that these differences are random. Table 4 reads from the row Regions the value $F=3.203498$ (1), i.e. $F$ crit $=2.866081$, then $95 \%$ for level of reliability or $\alpha=0.05$ for risk of error. Based on the ANOVA test, given that $F=3.203498>$ Fcrit $=2.86608$, we conclude that, at the risk of error of $5 \%$, null hypothesis $\mathrm{Ho} 2$ is accepted, and alternative hypothesis $\mathrm{Ha} 2$ is rejected. Given the above, we can conclude that differences in the number of successfully completed business negotiations, depending on regions are statistically significant. This means that success of business negotiations is significantly affected by country in which the analyzed trading companies operate. In addition, by applying $P$ value test, we can confirm that there is moderate evidence against the alternative hypothesis $\mathrm{Ha} 2$, since we have calculated $P=0,034702$ for given row, i.e. it is between $0.01<0.034702<$ 0.05 .

Since formulated null hypotheses Ho1 and Ho2 are accepted in cases, we can start with testing the impact of each individual data on business negotiations, by using the Least Significant Difference - LSD test. Data necessary for calculations are illustrated by Table 5 and Table 6 , wherein the analyzed symbols are marked with (a) - for cultural, political and economic factors, and (b) - for countries.

Table 5. LSD test for cultural, political and economic factors (a) of business negotiations in trade companies 
Marić R., Janać J.: Specific Characteristics of Business Negotiation in the SEE...

\begin{tabular}{|c|c|c|c|c|c|}
\hline $\begin{array}{l}\text { Arithmetic } \\
\text { mean } \overline{\boldsymbol{X} \boldsymbol{\imath}}\end{array}$ & $\overline{x_{l}}-4,8$ & $\overline{\boldsymbol{X}_{\boldsymbol{l}}}-5,4$ & $\overline{\boldsymbol{X} \boldsymbol{L}}-6,8$ & $\overline{X_{\imath}}-7$ & $\overline{X_{\boldsymbol{L}}}-8,8$ \\
\hline 9,6 & $4,8^{*}$ & $4,2^{*}$ & $2,8^{*}$ & $2,6^{*}$ & 0,8 \\
\hline 8,8 & $4,0^{*}$ & $3,4^{*}$ & 2,0 & 1,8 & - \\
\hline 7 & 2,2 & 1,6 & 0,2 & - & - \\
\hline 6,8 & 2,0 & 1,4 & - & - & - \\
\hline 5,4 & 0,6 & - & - & - & - \\
\hline 4,8 & - & - & - & - & - \\
\hline
\end{tabular}

Source: Author

Table 5 shows the differences between arithmetic means of the cultural, political and economic factors. Asterisk $\left({ }^{*}\right)$ after a number indicates a significant statistical differences for a given characteristic, i.e. confirms that the requirement $(\boldsymbol{X} t-\bar{X} t+1)>\operatorname{LSD}$ is met, where $\operatorname{LSD}(a)=2,3$; with $t_{0,05 ; 20}=2.086$, i.e. $S_{\left.\bar{x}_{i}-\bar{x}_{i+1}\right)}=1,14$. Based on a given formula, we conclude that Table 5 contains six statistically significant differences between factors: $a_{1}$ and $a_{2} ; a_{1}$ and $a_{4} ; a_{1}$ and $a_{5} ; a_{1}$ and $a_{6} ; a_{3}$ and $a_{5} ; a_{3}$ and $a_{6}$. This implies that during business negotiations in trade sector, managers pay attention to key factors, such as culture $\left(a_{1}\right)$ and tradition, custom and religion $\left(a_{3}\right)$.

Table 6. LSD test for countries (b) in which analyzed trade companies operate

\begin{tabular}{ccccc}
\hline $\begin{array}{c}\text { Arithmetic mean } \\
\overline{\boldsymbol{X}_{\boldsymbol{l}}}\end{array}$ & $\overline{\boldsymbol{X}_{\boldsymbol{l}}}-5,83$ & $\overline{\boldsymbol{X}_{\boldsymbol{l}}}-6,00$ & $\overline{\boldsymbol{X}_{\boldsymbol{l}}}-7,67$ & $\overline{\boldsymbol{X}_{\boldsymbol{l}}}-7,83$ \\
\hline 8,00 & $3,17^{*}$ & $2,00^{*}$ & 0,33 & 0,17 \\
7,83 & $2,00^{*}$ & $1,83^{*}$ & 0,16 & - \\
7,67 & $1,84^{*}$ & 1,67 & - & - \\
6,00 & 0,17 & - & - & - \\
5,83 & - & - & - & - \\
\hline
\end{tabular}

Source: Author

Table 6 shows the differences between arithmetic means for selected SEE countries. Asterisk $\left({ }^{*}\right)$ after a number indicates a significant statistical differences for a given characteristic, i.e. confirms that the requirement $(\bar{x} t-\bar{X} t+1)>\operatorname{LSD}$ is met, where $\operatorname{LSD}(\mathrm{b})=1.75$; with $t_{0,05 ; 20}=2.086$, i.e. $S_{\left(\bar{x}_{i}-\bar{x}_{i+1}\right)}=0.84$. We conclude that there are five statistically significant differences between countries, such as: $b_{1}$ and $b_{3} ; b_{1}$ and $b_{4} ; b_{2}$ and $b_{3} ; b_{2}$ and 
Marić R., Janać J.: Specific Characteristics of Business Negotiation in the SEE...

${ }_{b} 4 ; b_{3}$ and $b_{5}$, which means that trading companies operating in Serbia $\left(b_{1}\right)$, Croatia $\left(b_{2}\right)$ and Bosnia and Herzegovina $\left(b_{3}\right)$ are the most sensitive to the influence of mentioned factors in business negotiations.

Confirmed hypotheses tell us that there are statistically significant differences between the cultural, political and economic factors that affect business negotiation in trade companies. On the other hand, differences in terms of countries in which these companies operate are statistically significant for negotiation process. By cross-referencing the aforementioned characteristics and their ranking (scale 0 to 4 ) by model that the most sensitive factor in the most sensitive country receives the highest rank 4 (very significant impact), and so on, we can create profile of a manager - negotiator in trade companies, separately for each of the surveyed countries.

Figure 1. Ranking of factors' influence on negotiating process in trade companies operating in the selected SEE countries

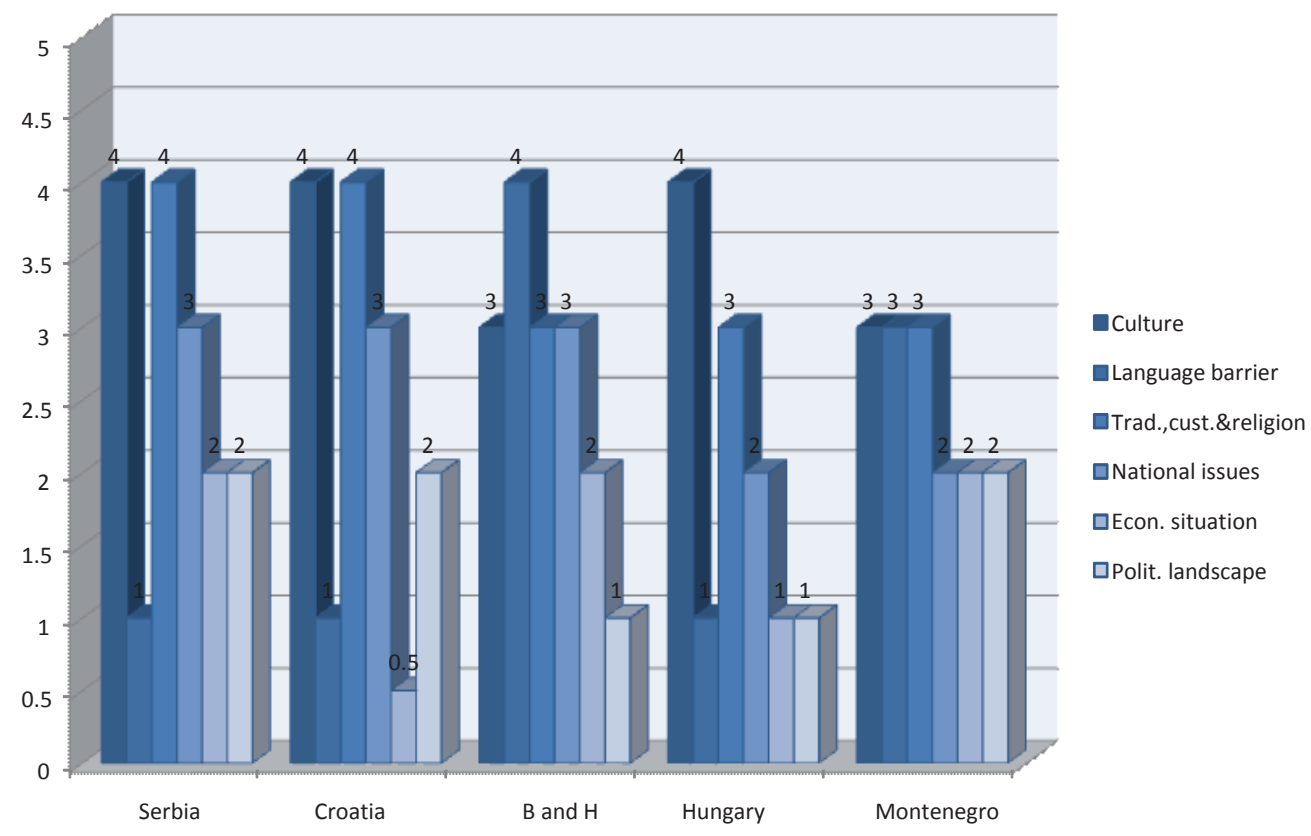

Source: Author

The following Figure 1 illustrates profile of a manager in charge of business negotiation in trade companies operating in the market of the selected SEE countries. The present model does present the expected standard of 
Marić R., Janać J.: Specific Characteristics of Business Negotiation in the SEE...

manager's behaviour when preparing for business negotiations. Meaning of appropriate rank of the analyzed characteristic is as follows: 4 - very significant impact; 3 - significant impact; 2 - moderate impact; 1 - relatively weak impact, 0 - no impact on negotiating process. For example, if a foreign company, organization, association, etc. wants to negotiate with trade companies operating on Serbian market, it may expect in negotiating process to encounter managers who believe that final result of negotiations is greatly influenced by cultural behaviour of negotiator, appreciation of Serbian tradition, custom and religion (rank 4), and accordingly, each preparation of negotiations implies full consideration of specified factors. In addition, significant attention should be paid to national issues (rank 3), while some less importance is given to knowledge of political landscape and economic indicators (rank 2). Finally, the smallest obstacle in negotiations are language barriers (rank 1).

In Croatian trading companies, as in the case of Serbia, the most important factors that influence the negotiation process are cultural norms (rank 4), then tradition, custom and religion (rank 4). National and political issues (rank 3) still considerably limit the factor of successful operations in the SEE countries, and unlike managers in Serbia, business negotiators in Croatia do not pay that much attention to the economic situation of the region (rank 0.5).

Bosnia and Herzegovina, as well as in the previous cases, is characterized by managers-negotiators who take cultural norms into account in the process of negotiating, as well as knowledge of tradition, custom and religion of the country where negotiations take place (rank 3). Surprisingly, managers reported that the biggest obstacle in the course of negotiating is language (rank 4), i.e. negotiation that takes place in foreign languages. Great significance is found in national issues (rank 3), while political and economic situation take the last place (rank 2).

Hungary, a full member of the European Union, is characterized by somewhat different situation compared to the previously analyzed countries. The first and most important factor affecting the success of negotiations of trade companies are exclusively cultural norms (rank 4) and behaviour of opposite parties in negotiations, which implies politeness, good manners, respect for participants, etc. Somewhat less importance is attached to tradition and custom (rank 3) and national issues (rank 2). At the very end, unlike countries in transition, are economic situation and political issues (rank 1).

Answers provided by managers working in trade companies in Montenegro were almost identical for all analyzed factors, and therefore they will be divided into two groups. The first group with rank 3 comprises factors, such as culture, tradition, custom, religion and language, which are typical for this region of SEE countries and often decisive for the process of starting 
Marić R., Janać J.: Specific Characteristics of Business Negotiation in the SEE...

negotiations. Managers attach less importance to national issues, economic conditions and politics (rank 2).

\section{Conclusion}

Need to analyze business negotiations in trade has arisen as a result of the growing importance of this sector in the overall economic development of the selected SEE countries, and the fact that it is exclusively a service sector, which is by nature of its activity dependent on the quality of human resources.

The main purpose of the conducted research was to show that key factors affecting the process of business negotiating in selected SEE trade companies are as follows: culture, tradition, custom, religion, national issues, language, political ideology and economic situation in analyzed countries. The focus of the research was to show on how to negotiate more efficiently, in the sense to provide managers with factors significant to opposite parties for achieving success and to which they pay attention during negotiations.

In this context, two main hypotheses have been set up. Ho1: there are statistically significant differences in the number of successfully completed commercial negotiations in selected SEE trade companies depending on the cultural, economic and political factors, and Ho2: there are statistically significant differences in the number of successfully completed commercial negotiations depending on the country where a trading company operates. Both hypotheses were confirmed by using ANOVA test and P-value. After that, the LSD-test was used for testing which of the analyzed factors has the greatest impact on the business negotiation. Factors were ranked based on the results of LSD test. The most important factors that influence the negotiation process are cultural norms with an average rank of 3.6, and tradition, custom and religion with an average rank of 3.4. National issues have somewhat less importance (average rank 2.6), followed by language barriers (average rank 2). The least important is economic and political landscape (average rank 1.5 and 1.6). If observed individually, by countries, there are no differences between ranked factors. Greatest difference is noticed regarding the language of negotiations. In Bosnia and Herzegovina, this factor is the most important one (rank 4), while in other countries it takes significantly lower rank. This case is similar to factor Economical situation, which in Croatia and Hungary takes the lowest rank, while in $\mathrm{BIH}$ and Montenegro it takes rank 4. The rest of the analyzed factors in given countries have equal ranking of their influence on success of business negotiations.

In addition, obtained results and confirmed hypotheses provide grounds for further researches that should focus on how certain subgroups within analyzed factors influence the negotiation process. For example, how moral 
Marić R., Janać J.: Specific Characteristics of Business Negotiation in the SEE...

standards, business etiquette, etc. within cultural factors, reflect on success of negotiations, or, in terms of political ideologies, whether negotiators who support ideology of the EU, U.S., Russia and Asian countries, China, Japan, etc. are more successful.

\section{References:}

Acin-Sigulinski, S., (2003). Međunarodno poslovno pregovaranje - iz arsenala taktika. Anali ekonomskog fakulteta, 10(10), 277-282.

American Management Association (2005). The Ethical Enterprise: A global study of business ethics 2005-2015. New York, USA.

Cohen, H., (1982). You Can Negotiate Anything: How to Get What You Want, New York, USA: Random House Digital, Inc.

Ćuzović, S. (2011). Uloga trgovine u unapređenju robne razmene Srbije sa inostranstvom. Ekonomske teme, 69(3), 449-465.

Dobrijević, G., (2009). Strategija poslovnog pregovaranja u savremenim organizacijama (Unpublished PhD thesis). Singidunum University, Belgrade, Serbia.

Dupuis, M., \& Prime, N., (1996). Business distance and global retailing: A model for analysis of key success/failure factors. International Journal of Retail \& Distribution Management, 24(11). 30-38.

Kaufman, L., \& Carter, S. (2004). Deciding on the Mode of Negotiation: To Auction or Not to Auction Electronically. Journal of Supply Chain Management, 40(1), 1526. doi: 10.1111/j.1745-493x.2004.tb00166.x

Križman-Pavlović, D., \& Kalanj, I., (2008). Uloga poslovnog pregovaranja u stjecanju konkurentske prednosti. Ekonomska istraživanja, 21(4), 62-81.

Lewicki, J.R., Saunders, M.D., \& Barry, B., (2009). Negotiation. Zagreb, Croatia: Mate.

Marić, R., Vemić-Đurković, J., \& Hevizi, T., (2012). Demografske karakteristike menadžera - profil potencijalnog poslovnog pregovarača u Srpskim preduzećima, Poslovna ekonomija, 6(2), 259-274.

Mintzberg, H. (1983). The case for corporate social responsibility. Journal for Business Strategy, 4(2), 3-15.

Miljković-Božić, I. (2012). Konkurentnost balkanskih zemalja u spoljnoj trgovini u uslovima globalizacije. Međunarodni problemi, 64(1), 67-81. doi: 10.2298/medjp1201067b

Neale, M., \& Bazerman, M. (1992). Negotiating rationally: the power and impact of the negotiator's frame, Academy of Management Perspectives, 6(3), 42-51.

Salacuse, J.W., (1991). Making Global Deal: Negotiating in the International Marketplace, Boston, USA: Houghton Mifflin.

Whalley, J., (1998), Why Do Countries Seek Regional Trade Agreements? In Frankel J.A., (Eds.), The Regionalization of the World Economy (pp. 63-90). Chicago, USA: University of Chicago Press.

Vojnović, B., Vojnović, D., \& Grujić, D (2011). Poslovanje domaćih preduzeća u okolnostima ekonomske krize, Industrija, 39(1), 201-216. 